\title{
Effect of agricultural landscape characteristics on the hydrobiota structure in small water bodies
}

\author{
Tomasz Joniak • Natalia Kuczyńska-Kippen • \\ Maciej Gąbka
}

Received: 17 January 2016/Revised: 1 July 2016/Accepted: 3 July 2016/Published online: 16 July 2016

(C) The Author(s) 2016. This article is published with open access at Springerlink.com

\begin{abstract}
Understanding the influence of environmental factors on the hydrobiota structure of small aquatic ecosystems is essential for effective landscape management. In this study of 165 small water bodies situated in the lowland high-productive agricultural landscape of western Poland we evaluate the effect of catchment, buffer zone, water body and water quality parameters on macrophyte functional groups (nymphaeids, elodeids, pleustophytes, helophytes) and zooplankton diversity. The potential pressure of the catchment on ponds was high (mean Ohle index 140). For macrophytes, shore length and depth of pond were highly significant and, subsequently the type of catchment and buffer, while for zooplankton, apart
\end{abstract}

Guest editors: Mary Kelly-Quinn, Jeremy Biggs \&

Stefanie von Fumetti / The Importance of Small Water

Bodies: Insights from Research

Electronic supplementary material The online version of this article (doi:10.1007/s10750-016-2913-5) contains supplementary material, which is available to authorized users.

T. Joniak $(\bowtie) \cdot$ N. Kuczyńska-Kippen

Department of Water Protection, Faculty of Biology, Adam Mickiewicz University, Umultowska 89,

61-614 Poznan, Poland

e-mail: tjoniak@amu.edu.pl

M. Gąbka

Department of Hydrobiology, Faculty of Biology, Adam Mickiewicz University, Umultowska 89, 61-614 Poznan, Poland from water depth, trophic features of the habitat were decisive. Cluster analysis was used to identify functional types of water bodies on the basis of catchment and buffer zone attributes. Regardless of physicogeographical macroregion, water bodies of arable catchments with herbage buffer prevailed in a landscape. For protection and prevention of ecological deterioration of ponds and stability of trophic conditions the optimal situation is a buffer which is created by shrubs and trees around the pond.

Keywords Small water bodies - Agricultural landscape $\cdot$ Hydrobiota structure $\cdot$ Land use . Catchment pressure - Buffer characteristics . Hydrochemistry $\cdot$ Nature conservation

\section{Introduction}

The approach taken to the management of the agricultural landscape, the dominant landscape type in Central Europe, is of critical importance for biodiversity conservation. Since landscape planning and management are generally conducted on wide spatial scales, the approaches adopted have a wide impact, which is particularly profound for aquatic habitats (Davies et al., 2009; Boix et al., 2012). In the Central European agricultural landscape small water bodies are the dominant aquatic landscape features, in terms of number and cumulative surface area, as well 
as being significant on both the local and global scale (e.g. Downing et al., 2006). However, changes in the use of agricultural areas in Europe, through the intensification of management (including large-area cultivations, agrotechnical practices, fertilization and drainage) along with the elimination or fragmentation of natural habitat networks (small water courses, water bodies and woodlots, wastelands) has significantly contributed to reduction in biodiversity, with particularly profound effects for small waters (Scheffer et al., 2006; Céréghino et al., 2008; Stoate et al., 2009). Unfortunately, knowledge of the role of small aquatic systems on landscape ecology and biodiversity in the agricultural landscape has only lately become available even though such knowledge is of considerable practical importance for the planning of landscape management.

Aquatic ecosystems, especially those of low water volume, are exposed to a variety of pollutants from both point and diffuse sources, which originate in the case of agricultural landscapes from sources such as runoff from farmland areas, rural wastewater effluents or airborne deposition. Ponds due to their small catchment areas are characterized by strongly differentiated hydrochemical parameters depending on land-use type and local hydrogeology. However, the quantity of matter received into lakes from their catchments is not proportional to their volume (Piotrowicz et al., 2006; Schindler, 2009). In intensively managed agricultural landscape these small bodies of water play the role of matter-traps (Gerke et al., 2010), biogeochemical barriers (Szpakowska \& Życzyńska-Bałoniak, 1994; Lischeid \& Kalettka, 2012), as well as hotspots for high biodiversity (Oertli et al., 2002; Williams et al., 2004; Pätzig et al., 2012). Research on small water bodies located in the natural and anthropogenically transformed landscape confirms significant variation in the quality of water (Joniak et al., 2007; Kuczyńska-Kippen \& Joniak, 2010; Gałczyńska \& Kot, 2010) and bottom sediments (Joniak \& Kuczyńska-Kippen, 2010).

Even though small water bodies occur throughout the European Lowlands, they prevail in certain regions e.g. in the late-glacial areas, where numerous depressions favour retention of water. In Poland the number of natural small water bodies is constantly decreasing reflecting trends worldwide (Boix et al., 2012). The main reason behind their elimination from the landscape, alongside the change of climate and hydrological droughts that periodically recur (Schindler, 2009; Céréghino et al., 2014), is the change in the type of agricultural economy from extensive to intensive, initiated at the turn of the eighteenth and nineteenth centuries. Economic changes caused the disappearance from the lowland areas of Europe of the functioning of the extensive agricultural economy and leading to agricultural landscape dominated by habitats that are strongly transformed (Declerck et al., 2006). Meanwhile, simplification of the agricultural landscape by eliminating balks, trees and shrubs that create buffer zones around small water bodies has intensified the negative effects from surrounding landuse activities.

The kind of catchment area and the way the land is used within the catchment area has a great impact on the hydrochemistry of small water bodies and for hydrobionts. Within community indices that are of high ecological relevance, diversity of organisms may be among very sensitive tools recognized for environmental assessment (e.g. Dobson, 2005; Beever, 2006). This is connected with the fact that communities may respond in a similar way to different stressors (Connon et al., 2012) connected e.g. with urban-originated nutrient enrichment or habitat degradation. This is particularly important for small water bodies, as they often exhibit a very high level of diversity, including many rare and threatened species, despite their small are and shallowness compared to larger aquatic ecosystems such as lakes or rivers.

The aim of the present study was to evaluate the effect of various types of land use and characteristics of the buffer zone on macrophytes and zooplankton inhabiting small water bodies. This paper is a part of current research describing the relationship between catchment and water quality in the context of small, lowland water bodies of the agricultural landscape. Specifically, we asked whether a widely known rule that the larger the catchment, the larger deterioration of water quality of a lake can also be transferred into shallow and small water bodies. We also evaluated whether the land use or type of buffer zone influenced hydrobiota structure and water quality specifically or whether observed impacts were the result of collective stressor effects. 


\section{Materials and methods}

Study site

The study was carried out in the area of the Wielkopolska Province (approx. 30,000 $\mathrm{km}^{2}$ ) in western Poland (geographical coordinates: in the north $52^{\circ} 58^{\prime} 10^{\prime \prime} \mathrm{N}, 16^{\circ} 34^{\prime} 10^{\prime \prime} \mathrm{E}$, in the south $51^{\circ} 35^{\prime} 50^{\prime \prime} \mathrm{N}$, $16^{\circ} 53^{\prime} 28^{\prime \prime} \mathrm{E}$, in the east $52^{\circ} 28^{\prime} 53^{\prime \prime} \mathrm{N}, 18^{\circ} 00^{\prime} 50^{\prime \prime} \mathrm{E}$, in the west $52^{\circ} 21^{\prime} 56^{\prime \prime} \mathrm{N}, 15^{\circ} 48^{\prime} 17^{\prime \prime} \mathrm{E}$ ), an area with a regional economy based on high-productivity agriculture. The study area was located within three physicogeographical macroregions (Kondracki, 2011): Great Poland Lakeland (120 ponds), Leszno Lakeland (32 ponds) and Southern Great Poland Lowland (13 ponds). Ponds were located in areas of relatively low land with dominance of flat or undulating plateaus and plains (75-100 m asl). In the Wielkopolska Province the proportion of forest is low (26\%) compared to agricultural areas (59\% incl. arable land 49\%). All the studied ponds were situated within an agricultural landscape or within rural settlements with scattered housing.

The study included 165 shallow water bodies (Online Resource 1) and was carried out during the summer season (June-August) in the years 2004-2013. Ponds were characterized in terms of length of shore (Shores), catchment area (Catchment), Ohle index (illustrated the catchment pressure, ratio of catchment area/pond area), \% share of land use form in the catchment (C-arable - arable, C-grass_-grassland, C-forest-forest, C-barren-barren land, C-ruralrural area) and characteristics of buffer strips (type of vegetation: B-herb-herbage, B-shrubs—shrubs, B-trees - trees, B-rush—rushes, length of shore with trees/shrubs vegetation (ShoreTS) and percentage share of trees/shrubs vegetation in relation to total length of shores (ShoresTS\%)). Buffer zones were defined as a usable area with semi-natural vegetation that surrounded the pond between the water surface and the nearest cultivated area or area used for agriculture. Pond area and length of shore (including the length of trees/shrubs vegetation) were measured in situ and catchment area state (especially in the area transformed by building developments) and forms of catchment use (in reference to orthophotomaps of high-resolution) were verified. A visual assessment of the contribution of different types of vegetation in the buffer zone was made. Maps, numerical elevation models and a base of geographical objects from the Polish National Spatial Data Infrastructure (www. mapy.geoportal.gov.pl) were used for the calculation of the area of the catchment.

Sampling and laboratory analysis

To avoid diurnal variation in both abiotic and biotic features, all field analyses and sampling were performed at the same time-around midday. In each pond electric conductivity (EC) was measured (Hanna Instruments HI-9146) and biological materials, as well as water for chemical laboratory analyses, were sampled. Water for chemical analyses was placed into polyethylene containers without conservation. Before analysis of chlorophyll, pretreatment filtration of the sample through a cotton filter (several layers of nonsterile cotton gauze placed in a PP funnel) was carried out (in the field) to separate foreign matter, such as insects, sediment, detritus, etc.

In each pond aquatic vegetation was described in terms of the number of nymphaeid $(\mathrm{N})$, elodeid $(\mathrm{E})$, pleustophyte $(\mathrm{P})$ and helophyte $(\mathrm{H})$ species. Some of the macrophyte species occurred only sporadically in the investigated water bodies, while others (e.g. Ceratophyllum demersum L., Typha latifolia L., Phragmites australis (Cav.) Trin. ex Steud) were very frequent and for this reason all macrophytes were grouped according to their ecological requirements (i.e. nymphaeids, elodeids, pleustophytes, helophytes). As various macrophyte types can contribute to varying degrees to an increase of overall zooplankton diversity (e.g. dense and complex elodeids vs. simple helophytes/nymphaeids), we decided to compare only zooplankton samples taken from the open water area. Zooplankton was sampled using a calibrated vessel. Initially, samples were collected in triplicate from each site and finally for species composition calculation the result of cumulative species number was applied. In order to avoid the effect of vertical change in the abiotic and biotic features and to obtain comparable material, all zooplankton samples were collected from the surface layer of water (Kuczyńska-Kippen \& Joniak, 2016). Samples were passed through a $45-\mu \mathrm{m}$ net and fixed immediately with $4 \%$ formalin. For the final calculations mean values of zooplankton densities were applied. The whole sample was checked to identify all zooplankton species present in each 51 sample. All 
cladocerans were identified to species level, while rotifers to the level of species in most cases and to genus for a restricted set of soft-bodied taxa which contract during sample preservation. Counting of zooplankton was performed in accordance with standard techniques recommended for this group of organisms (Mack et al., 2012).

Water samples were analysed in the laboratory to determine: total phosphorus (TP, after persulfate digestion), nitrate nitrogen $\left(\mathrm{NO}_{3}\right.$, with sulphanilic acid), dissolved inorganic nitrogen (DIN, as the sum of nitrate, nitrite and ammonium nitrogen) and total hardness (Hard, EDTA titration method). These analyses were carried out following standard methods as reported in APHA (1995). Chlorophyll $a$ concentration was measured spectrophotometrically with hot ethanol (PN-ISO 10260). Each sample was taken with the utmost care so as to limit the movement of water over the bottom or within the plant bed.

\section{Data analysis}

Principal Components Analysis (PCA) was used to visualize association between environmental variables, and between ponds and environmental variables, especially catchment and buffer zone features. PCA was undertaken using CANOCO for Windows 4.5 (ter Braak \& Šmilauer, 2002). To identify the main types of habitats we applied Ward hierarchical grouping with Euclidean distances. This hierarchical method uses an analysis of variance to evaluate distances between clusters (Legendre \& Legendre, 1998). For the purpose of cluster identification three variables sets were applied: type of catchment, characteristics of buffer strip, and together catchment and buffer. The Mann-Whitney $U$ test and ANOVA by the Kruskal-Wallis $H$ test were used to determine the significance of differences in the group of small water bodies on quality of water, aquatic vegetation and zooplankton structure. The data were subjected to a logarithmic transformation.

In order to calculate species diversity, quantitative data of the zooplankton were analysed by the Shannon-Weaver index (Margalef, 1957), which is a widely used method of calculating biotic diversity in a variety of aquatic ecosystems. A large value of the ShannonWeaver index indicates greater diversity, as influenced by a greater number and a more equitable distribution of species density in a community. The number of variables was reduced to include only the most important variables using the forward selection criterion based on the double stopping criterion (Blanchet et al., 2008). Variables were eliminated until the significance level of $P<0.05$ was achieved. Variables below the significance level of $P<0.05$ were presented on the diagrams passively. All the statistical analyses were performed using the $\mathrm{R}$ statistical package (R Development Core Team 2013, using the vegan package Oksanen, 2011).

\section{Results}

The studied water bodies were small (mean area $0.23 \mathrm{ha}$ ) and shallow (mean depth $1.1 \mathrm{~m}$, among them 90 ponds $\leq 1.0 \mathrm{~m}$; Online Resource 1). The potential pressure of the catchment on ponds was high (mean Ohle index was 140). Arable lands were the dominating form of catchment use (mean $67 \%$ of area, within them 57 ponds with $100 \%$ ). A feature of water chemistry was a moderate hardness and mineralization (mean conductivity $<1000 \mu \mathrm{S} \mathrm{cm}^{-1}$ ). PCA analysis showed that water hardness was highly correlated with shrubs/trees buffer vegetation, while conductivity with grassland and forest type of catchment along a minor importance of pond's surface and length of shores (Fig. 1). Overgrowing of banks by the trees/shrubs vegetation supported a clear beneficial effect of nutrients reduction in water, especially nitrates. However, the concentrations of TP and DIN were high in the examined ponds (mean $0.58 \mathrm{mg} \mathrm{P}^{-1}, 2.65 \mathrm{mg} \mathrm{N}^{-1}$, respectively).

Forward selection of environmental variables for macrophytes showed a significant role of the length of shores and depth of ponds, and subsequently the type of catchment area and buffer characteristics (Table 1). The content of phosphorus suggested much lower importance. For zooplankton, except the depth, trophic conditions of a habitat were among important environmental variables. Crustaceans were attributed at a high conductivity and at the lower level to DIN, while for rotifers the opposite was the case.

Type of catchment versus water quality and biocenotic structure

Cluster analysis extracted two types of catchment area of ponds: (1) barren-grassland-rural $(n=43)$ and (2) 


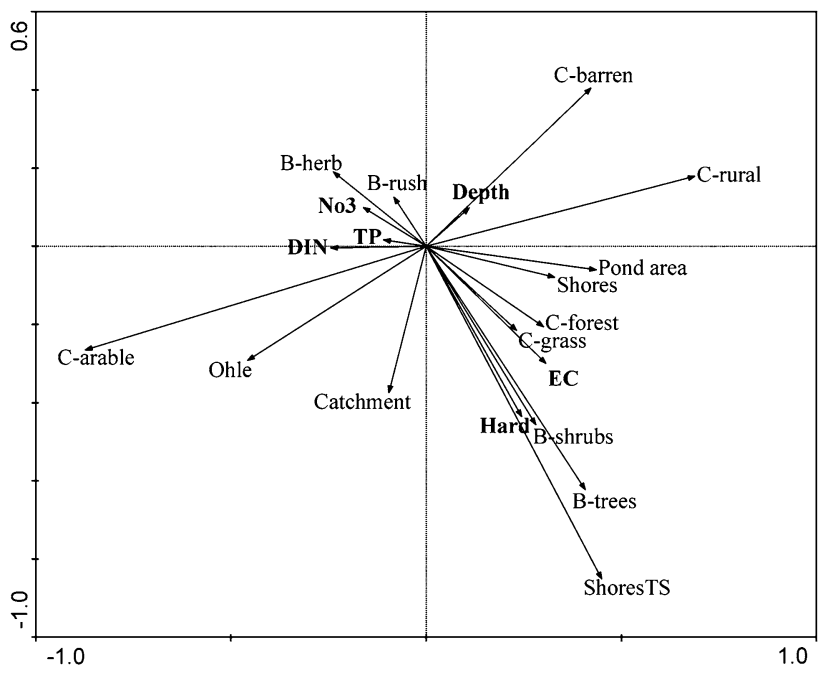

Fig. 1 Principal Component Analysis on environmental variables of ponds, catchment and buffer zone Legend: $E C$ electric conductivity, $\mathrm{TP}$ total phosphorus, $\mathrm{NO}_{3}$ nitrate, $\mathrm{DIN}$ dissolved inorganic nitrogen, Hard hardness; land use form in the catchment: $C$-arable arable, $C$-grass grassland, $C$-forest forest,

arable $(n=122)$ (Online Resource 2). In the study area, regardless of the macroregion, a clear domination of arable catchment was observed (Online Resource 3). A distinct feature of barren-grasslandrural type was that it had significantly the highest share of non-usable form of catchment, especially barren (Mann-Whitney test $P<0.0002$ ). In the quality of the buffer significant differences were obtained for shrubs and trees vegetation $(P<0.0018$ and $P<0.0076$, respectively) and for the shore length overgrown by this type of vegetation $(P<0.0018)$. The buffer zone of water bodies of the type 2 was mainly created by herbage vegetation $(P<0.372)$. Despite the fact that water bodies of mixed type of catchment area, compared to arable catchment, had a larger surface area $(P<0.0199)$ and smaller area of catchment, the variation in the water quality was not great. Between abiotic parameters of water significant differences were only obtained in relation to EC, which was significantly higher in the barren-grassland-rural type of catchment (Fig. 2). In those ponds within an agricultural catchment higher values of Shannon were only demonstrated for copepods $(P<0.453)$. No significant differences were found for other groups as well macrophytes and phytoplankton (Online Resource 2).
$C$-barren barren land, $C$-rural rural area; type of buffer vegetation: $B$-herb herbage, $B$-shrubs shrubs, $B$-trees trees, $B$-rush rushes; Shores TS length of shore with trees/shrubs vegetation

Table 1 Results of forward selection in the combined data explained by environmental variables, zooplankton community abundance (ind $1^{-1}$ ), ecological group of macrophytes and their significance assessed with 999 Monte Carlo permutation tests in RDA

\begin{tabular}{llll}
\hline Variable & $\lambda$ & $P$ & $F$ \\
\hline Macrophytes & & & \\
1. Shores length & 0.03 & 0.001 & 5.57 \\
2. Depth & 0.02 & 0.001 & 3.45 \\
3. Rural catchment & 0.02 & 0.002 & 2.49 \\
4. Herbage buffer & 0.01 & 0.009 & 2.28 \\
5. Total phosphorus & 0.01 & 0.013 & 2.24 \\
6. Arable catchment & 0.01 & 0.015 & 2.02 \\
Zooplankton & & & \\
Cladocera & & & \\
1. Conductivity & 0.03 & 0.002 & 5.91 \\
2. Depth & 0.03 & 0.001 & 5.00 \\
3. Inorganic nitrogen & 0.01 & 0.035 & 2.16 \\
4. Shores length & 0.01 & 0.037 & 2.08 \\
Rotifera & & & \\
1. Depth & 0.04 & 0.001 & 7.21 \\
2. Inorganic nitrogen & 0.02 & 0.001 & 3.45 \\
3. Conductivity & 0.01 & 0.032 & 1.96 \\
4. Rural catchment & 0.01 & 0.024 & 1.87 \\
\hline
\end{tabular}



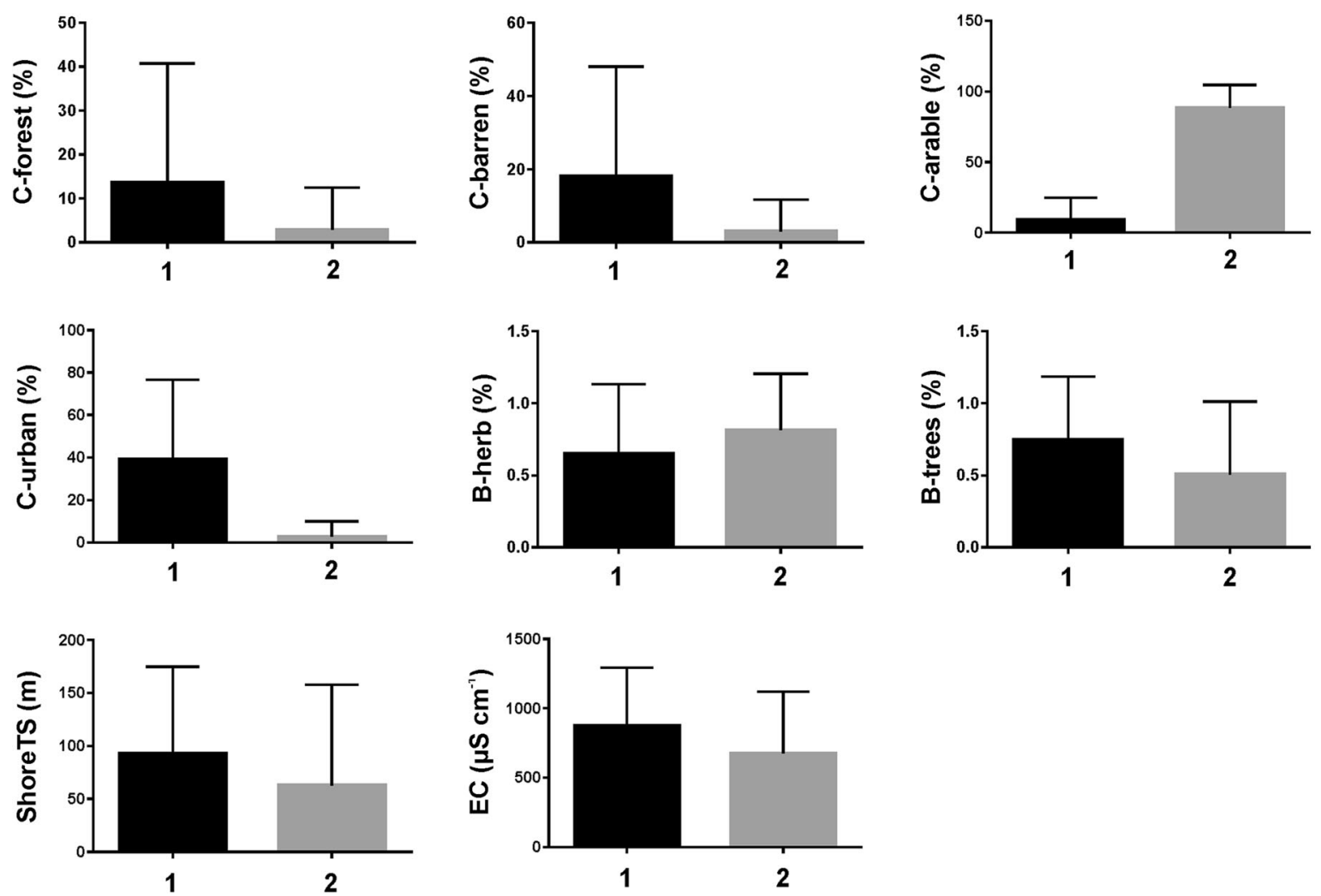

Fig. 2 Significant parameters in the analysis (Mann-Whitney $U$ test) of land use forms of catchment area: 1 barren-grassland-rural, 2 arable (box-mean, whiskers-SD)

Quality of buffer strip versus pond water quality and biocenotic structure

Cluster analysis extracted two types of buffer vegetation: (I) shrubs/trees $(n=39)$ and (II) herbage $(n=126)$. Type I was relatively more numerous in the Southern Great Poland Lowland macroregion, although generally buffer of type II dominated in mesoregions, especially in Leszno Lakeland (Online Resource 4). There were significant differences in case the length of the trees/shrubs formation around ponds (Mann-Whitney test $P<0.0001$; Fig. 3). Water bodies with shrubs/trees buffer were characterized by a significantly greater number of pleustophyte and by higher water hardness $(P<0.0442$ and $P<0.0152$, respectively). The ponds with herbage buffer had a significantly greater number of nymphaeid and were deeper $(P<0.0053$ and $P<0.2253$, respectively). No significant differences were recorded for other study hydrobiota (Online Resource 2).
Relations: type of catchment-quality of buffer strip and water quality-biocenotic structure

Based on clusters analysis of catchment land use and quality of buffer strip three groups of ponds were extracted: (A) of barren-rural catchment with shrubs/ herbage buffer $(n=46)$, and of arable catchment with (B) herbage buffer $(n=85)$ and (C) trees/shrubs buffer $(n=34)$. Representation of macroregions in types $\mathrm{A}$ and $\mathrm{C}$ (related by similar type of buffer zone vegetation) did not exceed $50 \%$ ponds, with the exception of the Southern Great Poland Lowland (Fig. 4). In Great Poland Lakeland and Leszno Lakeland the most numerous water bodies were those with typically agricultural catchment with poorly developed vegetation of the buffer zone. In this type of classification a highly significant difference was found for the depth of water (ANOVA, $P<0.0473$ ) and for the scale of the catchment pressure $(P<0.0006)$, despite lack of differences for the 
Fig. 3 Significant parameters in the analysis (Mann-Whitney $U$ test) of buffer strip characteristics: I shrubs/trees, II herbage (box-mean, whiskersSD) Legend: $N$ nymphaeids, $P$ pleustophytes, Hard hardness, $B$-shrubs shrubs, $B$-trees trees, ShoreTS length of shore with trees/ shrubs vegetation
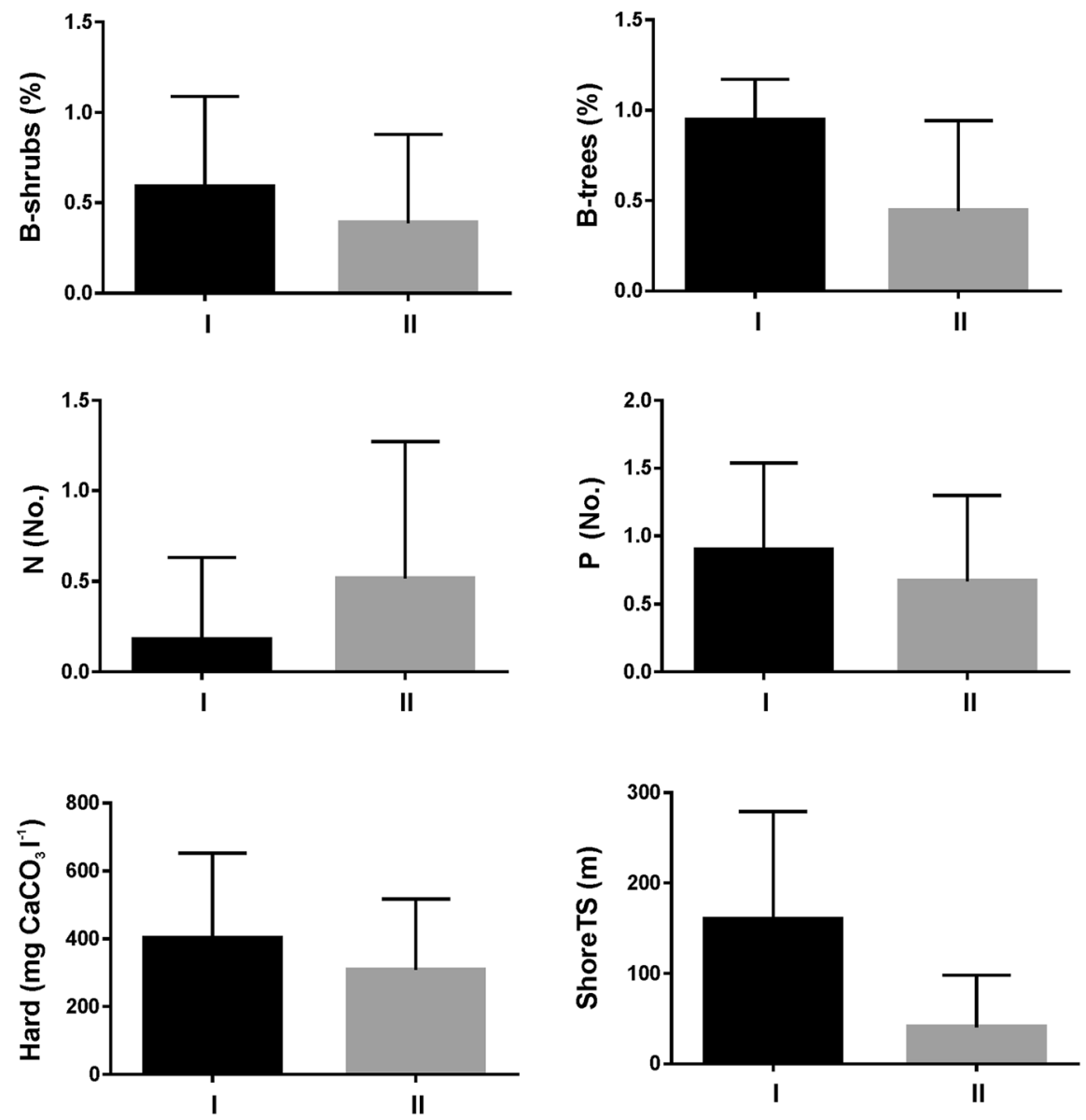

surface. The obtained groups differed substantially in most parameters related to forms of land use and to the kind of buffer zone. Shares of land use forms (except of grasslands) were highly significantly different (ANOVA, $P<0.0001$ ) (Fig. 5; Online Resource 2). The highest number of significant differences was found between the groups A and C. For buffer zone significant differences were noted for trees and herbage vegetation (Fig. 5) and for the shore length overgrown by trees and shrubs $(P<0.0001$; Fig. 6$)$. For other vegetation types the differences were weaker (Online Resource 2). In the most numerous group B, there were considerably larger shares of herbage vegetation and rushes.

In the case of hydrochemistry highly significant differences were recorded for the level of mineralization $(P<0.0020)$, while weaker differences were observed for the content of bivalent cations and nitrates $(P<0.0068$ and $P<0.0474$, respectively). The lowest concentrations of nitrate nitrogen were recorded in ponds of group C (Fig. 6). While the occurrence of aquatic macrophytes varied between the groups, significant differences were observed only for helophytes $(P<0.0472)$. No significant differences were recorded for zooplankton and phytoplankton (Online Resource 2).

\section{Discussion}

Study of the hydrobiota structure in small water bodies in a high-productive agricultural landscape showed a higher affinity of macrophytes for physical features of the examined ponds and catchment/buffer structure than of zooplankton. The role of shore length and depth of pond proves that the depth-area relation is an element of key significance for macrophytes. The importances of the colonized area and habitat size have already been indicated in relation to ephemeral water bodies (Brooks \& Hayashi, 2002). In turn, the 
Fig. 4 Dendrogram of cluster analysis on the basis of land use of the catchment area and the buffer quality with percentage share of ponds of macroregions Legend: GPL Great Poland Lakeland, $L L$ Leszno Lakeland, SGPL Southern Great Poland Lowland; particular clusters (groups of ponds): $A$ barren-rural catchment with shrubs/ herbage buffer, $B$ arable catchment with herbage buffer, $C$ arable catchment with trees/shrubs buffer
Information Remaining (\%)

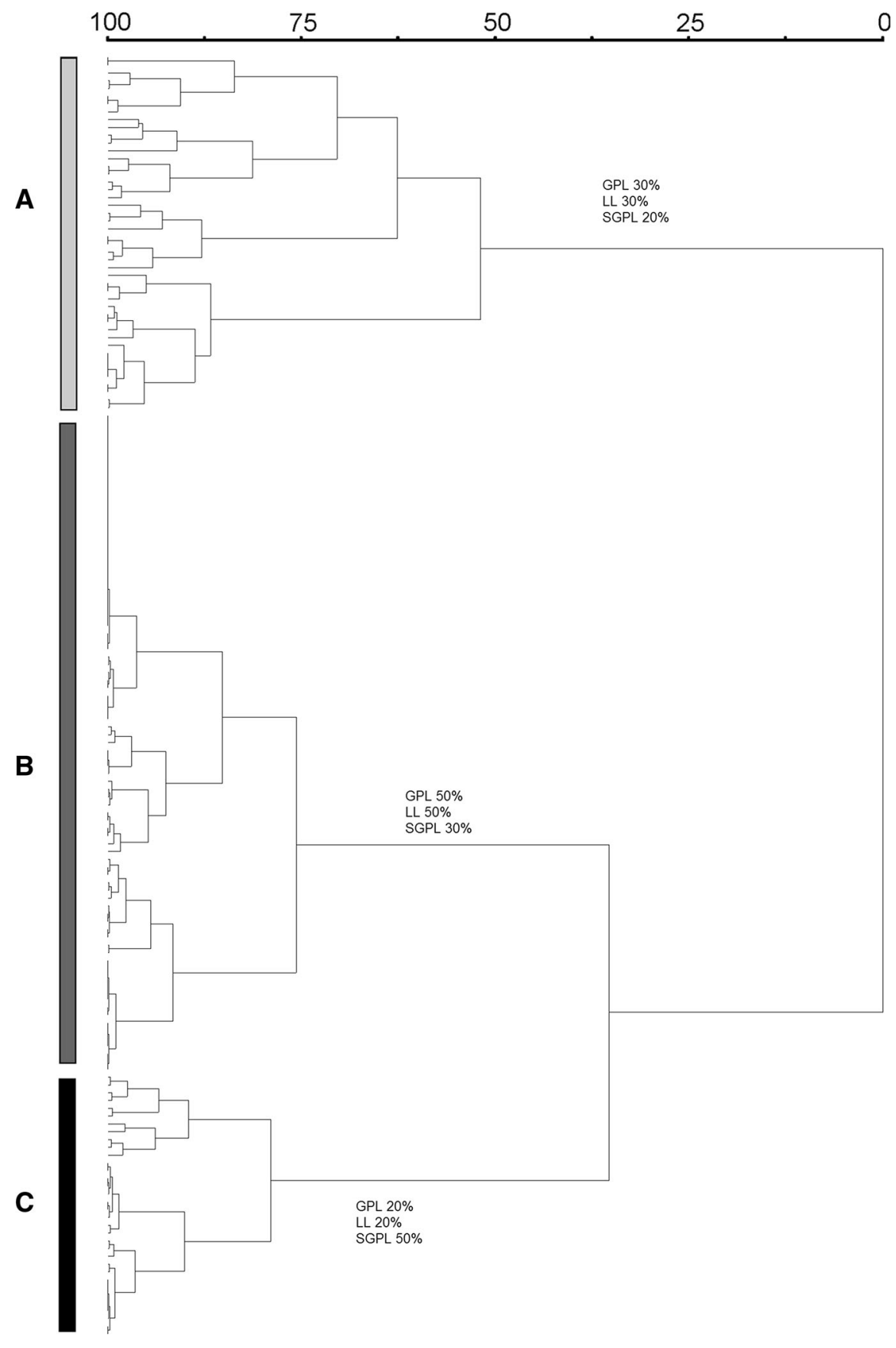

relationship between zooplankton and pond depth, conductivity and mineral nitrogen concentration suggests that the presence of macrophytes and fish are more important for both zooplankton abundance and diversity than catchment area conditions and quality of buffer strip. The key role of biotic drivers compared to catchment area conditions in structuring zooplankton community has also been ascertained in other studies, 

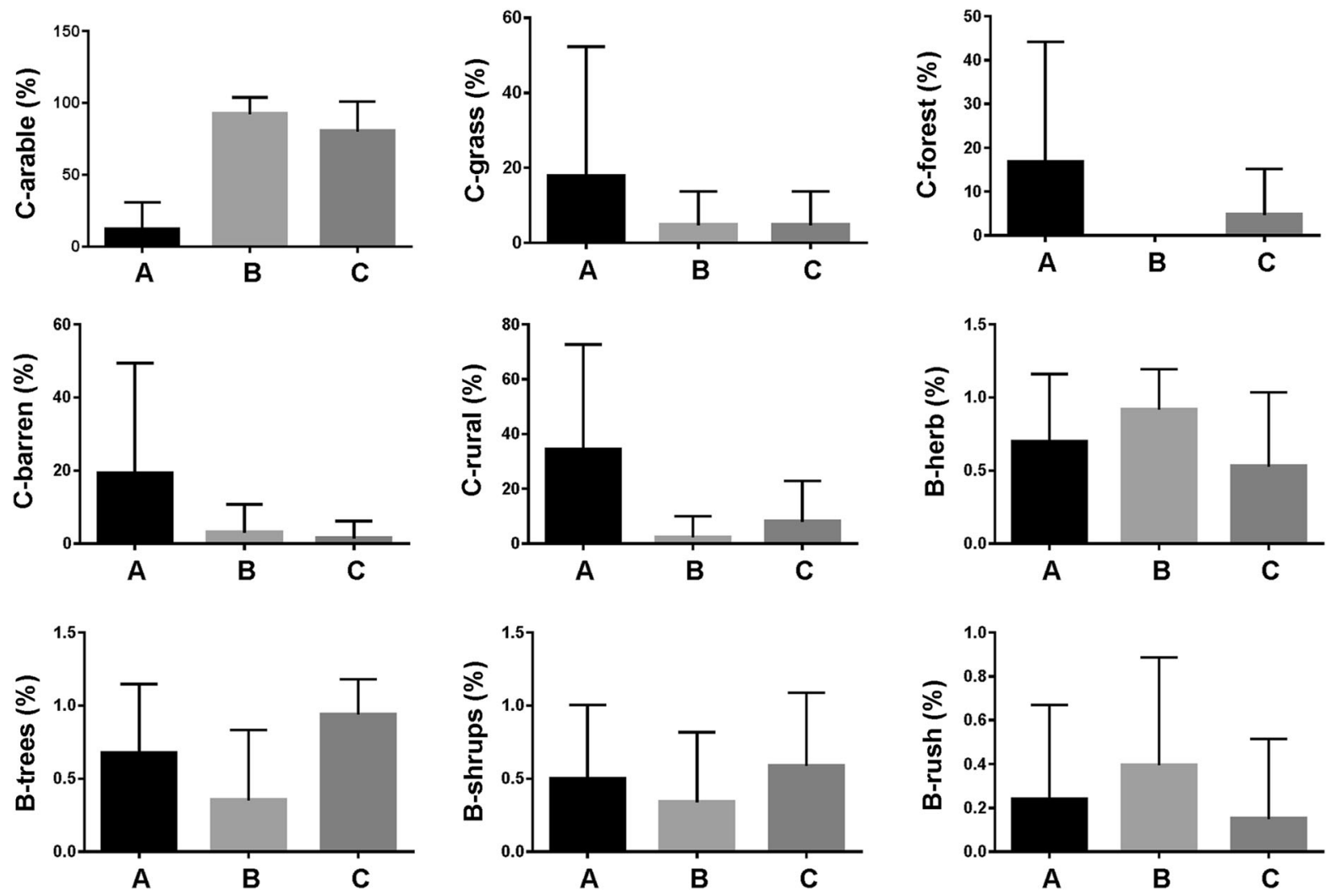

Fig. 5 Significant parameters in the analysis (ANOVA) of land use form of catchment area and buffer strip quality: $A$ barrenrural catchment with shrubs/herbage buffer, $B$ arable catchment with herbage buffer, $C$ arable catchment with trees/shrubs buffer (box-mean, whiskers-SD) Legend: land use form in the catchment: $C$-arable arable, $C$-grass grassland, $C$-forest forest, $C$-barren barren land, $C$-rural rural area; type of buffer vegetation: $B$-herb herbage, $B$-shrubs shrubs, $B$-trees trees, $B$ rush rushes

rotifers in small water bodies are associated with high trophic conditions of water in comparison to crustaceans, which preferentially chose ponds of low trophic conditions as also demonstrated by Kuczyńska-Kippen \& Joniak (2016). Another parameter that had a marked impact on plankton and macrophyte occurrence within the examined water bodies was depth of water. We found that crustacean diversity rose in shallow ponds, which may be connected with the weaker effect of fish in such ponds but also with the creation of favourable conditions for macrophyte occurrence, which contributes to increased crustacean variation (Lucena-Moya \& Duggan, 2011). The reverse effect to depth was especially true of nymphaeids, which were highly affected by the presence of deeper waters. Nymphaeids were often the only group of macrophytes occurring in conditions of low water transparency and phytoplankton 


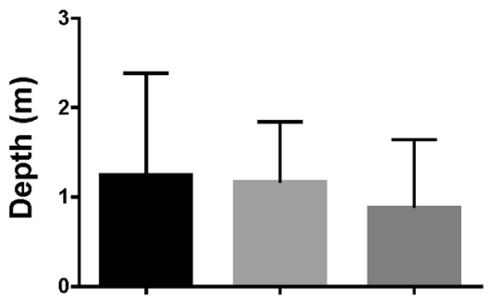

A

B

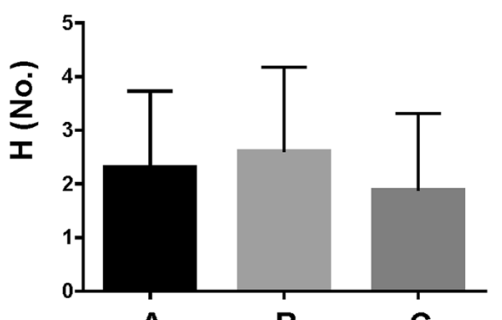

A

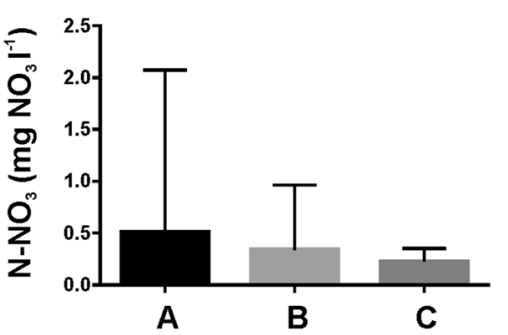

Fig. 6 Significant parameters in the analysis (ANOVA) of land use form of catchment area and buffer strip quality: $A$ barrenrural catchment with shrubs/herbage buffer, $B$ arable catchment with herbage buffer, $C$ arable catchment with trees/shrubs buffer

domination. Shallow depth of water and the consequent availability of light as well as high water hardness were optimal for the occurrence of elodeids. These conditions expressed a clear water state with low biomass of phytoplankton in accordance with the alternative stable state theory (Scheffer, 2001).

The assessment of the catchment on the basis of land use revealed only a small proportion of land other than the arable area. The separation of the relatively scarce subtype of barren-grassland-rural catchment demonstrates and confirms the weak diversification of the lowland agricultural landscape (Hazeli \& Wood, 2008). This fact is important for pond environments because the supply of biogenic elements will differ greatly, depending on the form of use and development of the catchment area. Export of phosphorus and nitrates from a structurally diversified landscape is less
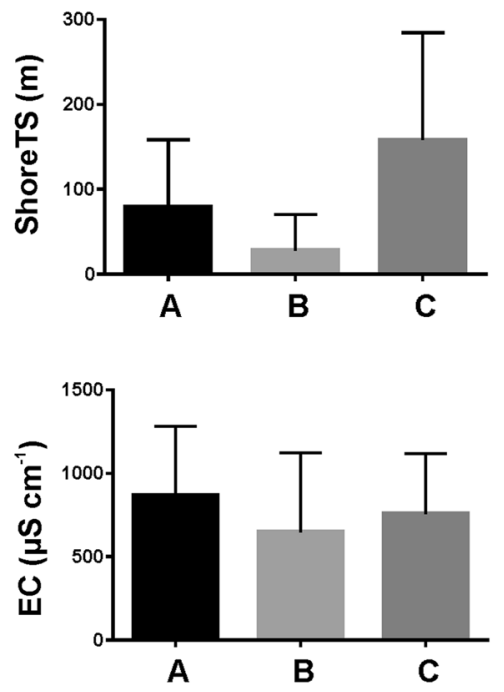

than from arable land (Szyper \& Gołdyn, 2002). The simplification of the structure of the agricultural catchment also involves the elimination or weakening of the barrier function of the buffer zones (Lischeid \& Kalettka, 2012) as a result of their fragmentation or the dominance of sod formation with herbage vegetation. In the studied ponds of arable catchment the higher content of nitrogen and phosphorus confirmed these findings. Optimal conditions for the development of biocoenosis, macrophyte and zooplankton diversity were represented by ponds located in landscape with more diverse spatial structure in rural catchment (as well as barren), which did not affect the concentration of biogenic and mineral compounds in water.

Buffer zones of small water bodies as a transition between ecosystems are a diversifying part of the agricultural landscape. The stable development of 
biocoenosis in small water bodies is possible through the elimination of the threat of excessive eutrophication. In this respect, shrubs and trees are a very favourable influence. A buffer in the form of trees and shrubs along a pond bank is more important for the quality of the habitat. The advantage of these species is their rapid growth and large capacity to absorb nitrogen and phosphorus (Labrecque \& Teodorescu, 2003). In buffers combining herbage and trees the effectiveness of retaining or removing nitrates through plant uptake or denitrification may reach up to $99 \%$ (Mayer et al., 2007). On the other hand, the presence of deciduous trees and shrubs near the water body increases the supply of nitrogen (Sobczyński \& Joniak, 2009), while coniferous organic matter and humic substances are received through leaf fall (Klimaszyk \& Rzymski, 2011). The occurrence of humic substances leads to changes in the abiotic features of water, in particular, a limitation of bioavailable nutrients (e.g. Górniak et al., 1999). A buffer composed of shrubs/trees is highly desirable from the point of view of biota as it promotes environmental enrichment in organic matter and shading of the surface of the water body, which is optimal for the development of pleustophytes (Gamrat et al., 2012) and rotifers (Kuczyńska-Kippen \& Basińska, 2014).

Our research has shown that approximately a quarter of the ponds did not have a buffer zone or, if they did, it had been reduced to herbaceous vegetation. This type of vegetation is a weak barrier for migration of nutrients that stimulate eutrophication, especially of easy bioavailable nitrates and phosphates (Hefting et al., 2006; Ryszkowski \& Kędziora, 2007), even more so if they are not mowed and biomass remains in the buffer area (Dorioz et al., 2006).

It can be concluded that the obvious role of the catchment area and buffer zones, which determine the water quality of large water bodies, is not simply reflected in the case of small water bodies. The quality and variety of aquatic biocoenosis is clearly dependent on land use and the state of the buffer zone. This means that for water biota microhabitat conditions are crucial and factors affecting the quality of conditions are implemented in accordance with the alternative stable states theory. It has been shown that in the conditions of an intensive agricultural economy, a full picture of the relationship between features of the habitat and biocoenosis of small water bodies is only possible as a result of combined analysis including both the catchment and buffer attributes. It was found that in this type of landscape, due to overloading considered in macroscale, a balancing of quality structure of the catchment and maintenance of the buffer zone with developed undergrowth vegetation together with shrubs/trees in shallow water bodies does not give the desired effect of high water quality.

A combined analysis that took into consideration the attributes of the catchment area and the buffer zone gave the opportunity to answer the question as to what type of diversity of the landscape and the pond's immediate surroundings is optimal for the habitat of a small water body. The most favourable conditions of habitats, despite the strongest pressure from the catchment (Ohle index $>150$ ) appeared in the case of arable catchment with a buffer of trees/shrubs from among the three distinguished types of catchment area. The best relative water quality with low nitrate content was evident here. The scope of variation in the conductivity and water hardness was also the lowest. This confirms the important role of shrubs and tree vegetation in the buffer zone, even without herbage vegetation. The compactness of the belt of shrubs/trees around ponds (>80\%) building root architecture was crucial (Ryszkowski \& Kędziora, 2007). An abundant development of algae and poor differentiation of zooplankton with the domination of small forms, typical for high trophy (Kuczyńska-Kippen \& Joniak, 2016), was a feature of plankton hydrobiota. The second type distinguished within the arable catchment with buffer limited to undergrowth vegetation, had all the features of overfertilization of a habitat by nitrogen and phosphorus compounds. This confirms the impaired or complete absence of the barrier function when the buffer is overgrown only by herbaceous plants and at the same time is devoid of the soil root architecture of trees and shrubs (Meyer et al., 2007). Those ponds located within a barren-rural catchment with shrubs/herbage buffer underwent the least impact from the catchment area. The lowest contents of TP and DIN compared to the two remaining types were reflected in the weaker growth of phytoplankton. Similar biocoenosis-biotope relationships were noted in sub-urban ponds (KuczyńskaKippen \& Joniak, 2010).

The results of our study offer the possibility to determine the features of natural environment, which in an intensively managed catchment may prevent ecological deterioration of ponds. The optimal structure of the buffer zone in an arable catchment of the 
lowland landscape should consist of herbaceous vegetation band (min width of $5 \mathrm{~m}$, range to the water line) and a band of deciduous species of native shrubs and trees (without the bank line). Coniferous vegetation is not expedient as it inhibits the growth of herbaceous species (e.g. Craine \& Orians, 2004) and alters the water chemistry (Klimaszyk et al., 2015). The proposed type of buffer effectively limits the flow of nutrients from surface and soil runoff and increases the supply of organic matter, which enhances the potential of the biocoenosis development.

Acknowledgements This research work was financed by the Polish State Committee for Scientific Research in 2010-2014 as research project N N305 042739. The authors are thankful to PhD Barbara Nagengast for identification of macrophytes.

Open Access This article is distributed under the terms of the Creative Commons Attribution 4.0 International License (http:// creativecommons.org/licenses/by/4.0/), which permits unrestricted use, distribution, and reproduction in any medium, provided you give appropriate credit to the original author(s) and the source, provide a link to the Creative Commons license, and indicate if changes were made.

\section{References}

APHA, 1995. Standard methods for the examination of water and wastewater, 9th ed. American Public Health Association, Washington, D.C.

Beever, E. A., 2006. Monitoring biological diversity: strategies, tools, limitations and challenges. Northwest Naturalist 87(1): 66-79.

Blanchet, F. G., P. Legendre \& D. Borcard, 2008. Forward selection of explanatory variables. Ecology 89(9): 2623-2632.

Boix, D., J. Biggs, R. Céréghino, A. P. Hull, T. Kalettka \& B. Oertli, 2012. Pond research and management in Europe: "Small is Beautiful". Hydrobiologia 689: 1-9.

Brooks, R. T. \& M. Hayashi, 2002. Depth-area-volume and hydroperiod relationships of ephemeral (vernal) forest pools in southern New England. Wetlands 22: 247-255.

Céréghino, R., J. Biggs, B. Oertli \& S. Declerck, 2008. The ecology of European ponds: defining the characteristics of a neglected freshwater habitat. Hydrobiologia 597(1): 1-6.

Céréghino, R., D. Boix, H.-M. Cauchie, K. Martens \& B. Oertli, 2014. The ecological role of ponds in a changing world. Hydrobiologia 723: 1-6.

Connon, R. E., J. Geist \& I. Werner, 2012. Effect-based tools for monitoring and predicting the ecotoxicological effects of chemicals in the aquatic environment. Sensors (Basel) 12(9): 12741-12771.

Craine, S. I. \& C. M. Orians, 2004. Pitch pine (Pinus rigida Mill.) invasion of Cape Cod pond shores alters abiotic environment and inhibits indigenous herbaceous species. Biological Conservation 116: 181-189.
Davies, B., J. Biggs, P. Williams \& S. Thompson, 2009. Making agricultural landscapes more sustainable for freshwater biodiversity: a case study from southern England. Aquatic Conservation: Marine and Freshwater Ecosystems 19: 439-447.

Declerck, S., T. De Bie, D. Ercken, H. Hampel, S. Schrijvers, J. V. Wichelen, V. Gillard, R. Mandiki, B. Losson, D. Bauwens, S. Keijers, W. Vyverman, B. Goddeeris, L. De Meester, L. Brendonck \& K. Martens, 2006. Ecological characteristics of small farmland ponds: associations with land use practices at multiple spatial scales. Biological Conservation 131(4): 523-532.

Dobson, A., 2005. Monitoring global rates of biodiversity change: challenges that arise in meeting the Convention on Biological Diversity (CBD) 2010 goals. Philosophical Transactions of the Royal Society B: Biological Sciences 360(1454): 229-241.

Dorioz, J. M., D. Wang, J. Poulenard \& D. Trévisan, 2006. The effect of grass buffer strips on phosphorus dynamics: A critical review and synthesis as a basis for application in agricultural landscapes in France. Agricultural Ecosystems \& Environment 117(1): 4-21.

Downing, J. A., Y. T. Prairie, J. J. Cole, C. M. Duarte, L. J. Tranvik, R. G. Striegl, W. H. McDowell, P. Kortelainen, N. F. Caraco, J. M. Melack \& J. J. Middelburg, 2006. The global abundance and size distribution of lakes, ponds and impoundments. Limnology and Oceanography 51: 2388-2397.

Gałczyńska, M. \& M. Kot, 2010. Influence of anthropopression on concentration of biogenic compounds in small of water ponds in farmland. Journal of Elementology 15(1): 53-63.

Gamrat, R., M. Gałczyńska \& K. Pacewicz, 2012. Spatial analysis of plant species distribution in midfield ponds in an agriculturally intense area. Polish Journal of Environmental Studies 21(4): 871-877.

Gerke, H. H., S. Koszinski, T. Kalettka \& M. Sommer, 2010. Structures and hydrologic function of soil landscapes with kettle holes using an integrated hydropedological approach. Journal of Hydrology 393: 123-132.

González, M. J., 1998. Spatial segregation between rotifers and cladocerans mediated by Chaoborus. Hydrobiologia 387: 427-436.

Górniak, A., E. Jekatieryńczuk-Rudczyk \& P. Dobrzyń, 1999. Hydrochemistry of three dystrophic lakes in northeaster Poland. Acta hydrochimica et hydrobiologica 27: 12-18.

Hazeli, P. \& S. Wood, 2008. Drivers of change in global agriculture. Philosophical Transactions of the Royal Society B: Biological Sciences 363(1491): 495-515.

Hefting, M., B. Beltman, D. Karssenberg, K. Rebel, M. van Riessen \& M. Spijker, 2006. Water quality dynamics and hydrology in nitrate loaded riparian zones in the Netherlands. Environonmental Pollution 139(1): 143-156.

Joniak, T., N. Kuczyńska-Kippen \& B. Nagengast, 2007. The role of aquatic macrophytes in microhabitatual transformation of physical-chemical features of small water bodies. Hydrobiologia 584: 101-109.

Joniak, T. \& N. Kuczyńska-Kippen, 2010. The chemisty of water and bottom sediments in relation to zooplankton biocenosis in small agricultural ponds. Oceanological and Hydrobiological Studies 39(2): 85-96. 
Klimaszyk, P. \& P. Rzymski, 2011. Surface runoff as a factor determining trophic state of midforest lake (Piaseczno Małe, North Poland). Polish Journal of Environmental Studies 20: 1203-1210.

Klimaszyk, P., P. Rzymski, R. Piotrowicz \& T. Joniak, 2015. Contribution of surface runoff from forested areas to the chemistry of a through-flow lake. Environmental Earth Sciences 73(8): 3963-3973.

Kondracki, J., 2011. Regional geography of Poland. PWN Press, Warsaw.

Kuczyńska-Kippen, N., 2009. The spatial segregation of zooplankton communities with reference to land use and macrophytes in shallow Lake Wielkowiejskie (Poland). International Review of Hydrobiology 94(3): 267-281.

Kuczyńska-Kippen, N. \& A. Basińska, 2014. Habitat as the most important influencing factor for the rotifer community structure at landscape level. International Review of Hydrobiology 99(1-2): 58-64.

Kuczyńska-Kippen, N. \& T. Joniak, 2010. Chlorophyll a and physical-chemical features of small water bodies as indicators of land use in the Wielkopolska region (Western Poland). Limnetica 29: 163-169.

Kuczyńska-Kippen, N. \& T. Joniak, 2016. Zooplankton diversity and macrophyte biometry in shallow water bodies of various trophic state. Hydrobiologia 774(1): 39-51.

Kuczyńska-Kippen, N. \& B. Nagengast, 2006. The influence of the spatial structure of hydromacrophytes and differentiating habitat on the structure of rotifer and cladoceran communities. Hydrobiologia 559(1): 203-212.

Labrecque, M. \& T. I. Teodorescu, 2003. High biomass yield achieved by Salix clones in SRIC following two 3-year coppice rotations on abandoned farmland in southern Quebec, Canada. Biomass \& Bioenergy 25: 135-146.

Legendre, P. \& L. Legendre, 1998. Numerical ecology. Elsevier, Amsterdam.

Lischeid, G. \& T. Kalettka, 2012. Grasping the heterogeneity of kettle hole water quality in Northeast Germany. Hydrobiologia 689: 63-77.

Lucena-Moya, P. \& I. C. Duggan, 2011. Macrophyte architecture affects the abundance and diversity of littoral microfauna. Aquatic Ecology 45(2): 279-287.

Mack, H. R., J. D. Conroy, K. A. Blocksom, R. A. Stein \& S. A. Ludsin, 2012. A comparative analysis of zooplankton field collection and sample enumeration methods. Limnology and Oceanography: Methods 10(1): 41-53.

Margalef, R., 1957. Information theory in ecology. General Systems 3: 36-71.

Mayer, P. M., S. K. Reynolds, M. D. McCutchen \& T. J. Canfield, 2007. Metaanalysis of nitrogen removal in riparian buffers. Journal of Environmental Quality 36(4): 1172-1180.

Obertegger, U. \& M. Manca, 2011. Response of rotifer functional groups to changing trophic state and crustacean community. Journal of Limnology 70(2): 231-238.

Oertli, B., J. D. Auderset, E. Castella, R. Juge, D. Cambin \& J.B. Lachavanne, 2002. Does size matter? The relationship between pond area and biodiversity. Biological Conservation 104: 59-70.

Oksanen, J., 2011. Multivariate analysis of ecological communities in $\mathrm{R}$ : vegan tutorial. $\mathrm{R}$ package version. http://cc. oulu.fi/ jarioksa/opetus/metodi/vegantutor.pdf.
Pätzig, M., T. Kalettka, M. Glemnitz \& G. Berger, 2012. What governs macrophyte species richness in kettle hole types? A case study from Northeast Germany. Limnologica 42: 340-354.

Perrow, M. R., A. J. D. Jowitt, J. H. Stansfield \& G. L. Phillips, 1999. The practical importance of the interactions between fish, zooplankton and macrophytes in shallow lake restoration. Hydrobiologia 395: 199-210.

Piotrowicz, R., M. Kraska, P. Klimaszyk, H. Szyper \& T. Joniak, 2006. Vegetation richness and nutrient loads in 16 lakes of Drawienski National Park (northern Poland). Polish Journal of Environmental Studies 15(3): 465-476.

Ryszkowski, L. \& A. Kędziora, 2007. Modification of water flows and nitrogen fluxes by shelterbelts. Ecological Engineering 29(4): 388-400.

Scheffer, M., 2001. Alternative attractors of shallow lakes. The Scientific World 1: 254-263.

Scheffer, M., G. J. van Geest, K. Zimmer, E. Jeppesen, M. Søndergaard, M. G. Butler, M. A. Hanson, S. Declerck \& L. De Meester, 2006. Small habitat size and isolation can promote species richness: second-order effects on biodiversity in shallow lakes and ponds. Oikos 112(1): 227-231.

Schindler, D. W. 2009. Lakes as sentinels and integrators for the effects of climate change on watersheds, airsheds and landscapes. Limnology and Oceanography 54 (6, part 2): 2349-2358.

Sobczyński, T. \& T. Joniak, 2009. Vertical changeability of physical-chemical features of bottom sediments in three lakes in aspect type of water mixis and intensity of human impact. Polish Journal of Environmental Studies 18(6): 1091-1097.

Stoate, C., A. Baldi, P. Beja, N. D. Boatman, L. Herzon, A. van Doorn, G. R. de Snoo, L. Rakosy \& C. Ramwell, 2009. Ecological impacts of early 21 st century agricultural change in Europe - A review. Journal of Environmental Management 91: 22-46.

Szpakowska, B. \& I. Życzyńska-Bałoniak, 1994. The role of biogeochemical barriers in water migration of humic substances. Polish Journal of Environmental Studies 3(2): $35-41$.

Szyper, H. \& R. Gołdyn, 2002. Role of catchment area in the transport of nutrients to lakes in the Wielkopolska National Park in Poland. Lakes \& Reservoirs: Research \& Management 7(1): 25-33.

ter Braak, C. J. F. \& P. Šmilauer, 2002. CANOCO reference manual and CanoDraw for Windows user's guide: software for canonical community ordination (version 4.5). Microcomputer Power, Ithaca.

Threlkeld, S. T. \& E. M. Choinski, 1987. Rotifers, cladocerans and planktivorous fish: What are the major interactions? Hydrobiologia 147(1): 239-243.

Van Onsem, S., S. De Backer \& L. Triest, 2010. Microhabitatzooplankton relationship in extensive macrophyte vegetations of eutrophic clear-water ponds. Hydrobiologia 656(1): 67-81.

Williams, P., M. Whitfield, J. Biggs, S. Bray, G. Fox, P. Nicolet \& D. Sear, 2004. Comparative biodiversity of rivers, streams, ditches and ponds in an agricultural landscape in Southern England. Biological Conservation 115: 329-341. 